DOI: 10.2478/auseur-2020-0006

\title{
Reverse Logistics Tasks Tested with Path Models Based on Data of Companies Operating in Hungary
}

\section{Mónika PÓNUSZ, ${ }^{1}$ Márton GOSZTONYI, ${ }^{1}$ Györgyi KŐVÁGÓ, ${ }^{1}$ Tímea KOZMA²}

\author{
${ }^{1}$ Károli Gáspár University of the Reformed Churched in Hungary, Budapest \\ e-mails: ponusz.monika@kre.hu; gosztonyi.marton@kre.hu; kovago.gyorgyi@kre.hu \\ ${ }^{2}$ Budapest Business School, Budapest \\ e-mail: kozma.timea@uni-bge.hu
}

\begin{abstract}
Our research in progress is aimed at discovering how sustainable development and reverse logistics appear in the practice of companies in Hungary. Our goal is to develop an analysis framework and test it on a Hungarian sample that examines the relationship between the elements of the reverse logistics system and logistics practices. This was tested on the available sample. In the course of observing the supply chains, we intend to focus on trends of sustainable development, with an outlook on the international practice. We pay special attention to the reverse logistics aspects of company practice, presenting the logistical processes according to the environmental challenges. The background of our analyses consists of processing the literature and conducting primer assessment.
\end{abstract}

Keywords: management, environmental economics, logistics, supply chains, sustainability

\section{Introduction}

\section{Sustainable Logistics}

Concerning sustainable development, we have to reach back to the interpretation given by the 1987 Brundtland Committee, according to which 'sustainable development is development that satisfies the needs of the present without threatening the chances of future generations to satisfy their own needs' (WCED 1987). 
The climate change with its effects being felt more and more, the threat of the finite nature of resources, and the matter of the urgent necessity of energy safety made it clear that decreasing fossil fuel use on a global scale must become unavoidable. Therefore, the operational framework of companies must be established so that it is in line with present expectations. This is what Harangozó also refers to in his writing when he emphasizes that: 'in different company functions (for example, production management, logistics, innovation management, finances, accounting, and marketing), there are several partial goals that can be compatible with the goal of decreasing the carbon footprint and for the realization of which it can be useful to quantify the corporate carbon footprint, integrating it in the corporate IT system and communicating it' (Harangozó 2016: 129-146). ${ }^{1}$

A sustainable supply chain presupposes the existence of good corporate practices, i.e. the development of sustainable sourcing and sustainable logistics (Harangozó et al. 2019: 13-21).

The Brundtland definition of sustainable development has an ethical, not an economic nature since it aims at reaching equality between generations and considers the matter from the perspective of humans and not that of nature. Sustainable development assumes ecological, social, and economic sustainability as a simultaneous harmony.

Business ethics is about how we conduct business according to ethical expectations. This means that we follow the business goals and meet well-defined limits (Oláh et al. 2018a: 95-100, 2018b: 269-289, 2018c: 194-200).

On the one hand, what needs to be met due to the business objective is to maximize shareholder value over the long term. On the other hand, long-term goals require conviction, and confidence is achieved through trust, and, consequently, compliance with constraints is a prerequisite for trust (Veres 2019: 847-855).

Supply chains are being networked. The joint interaction of several factors also influences the number of supply chains the individual companies have to have a role in (Kozma 2018: 23-35). Complex processes happen when companies that specialized in something due to globalization become part of a network (TóthGyenge 2018: 36-45).

Several definitions have emerged in recent years to formulate supply chain management (Stevens 1989: 3-8, Christopher 1992, Lambert et al. 1998, Cigolini et al. 2004: 7-41, Lalonde-Masters 1994: 35-47).

Literature analysis shows that a significant number of works have been published on sustainable supply chains, which form the broader framework of the model.

In their article, Carter and Easton (2011: 46-62) deal with the evolution and future directions of sustainable supply chain management.

Another literature analysis revealed that most resource-based views (theories) are related to the ideas of institutional economics (Touboulic-Walker 2015: 16-42).

1 Translated into English by the author. 
Due to the coordination of cross-company processes, the governance model is an unavoidable issue in sustainable supply chain research (Formentini-Taticchi 2016: 1920-1933).

According to the basic concept of our research, the reverse/green logistics concern a small segment from the green supply chain, besides which, for example, green supply chain design, green supply chain realization, and carbon management can be found. The basic concept for the Green Supply Chain book of Emmett and Sood (2010: 35) provides one of the most complex and thorough perceptions on the topic (Pónusz-Kozma 2017: 61-66). The SCORE model (Supply Chain Council 2006) is in accordance with it; according to its perception, we consider the entire supply chain keeping sustainability - that is, the green supply chain concept (Pónusz-Kozma 2017: 61-66) - in mind in every link in the chain. It studies processes in a complex manner, considering the multi-directional flow of materials and reverse processes, and it is also the basic model of our research (Kozma-Pónusz 2016: 1-181).

Based on our research precedents, we present the essence of $4 R$ through examples obtained from the responses of in-depth interviews:

Pónusz and Horváth (2014: 150-157) discuss the tasks of reverse logistics with an emphasis on food industry; the theoretical basis for the research was the $4 \mathrm{R}$ model, according to which we can distinguish between prior and subsequent tasks.

We will particularly take a look at the 4R model: R1: Reduction, R2: Replacement, R3: Reusing, and R4: Recycling (Déri-Vándorffy 2005: 50-58), based on which we are able to distinguish between preceding and posterior functions.

The first preceding task is to reduce the proportion, amount of raw materials (R1: Reduction at the source), the basic principle of which is to prevent waste generation. An excellent example of this in the food industry is reducing the amount of materials used in wine treatment technologies, the weight of the labels, the amount of adhesive, using PET bottles of decreased weight, or not using packaging where it is possible.

In the order of preceding tasks, the following is the replacement of traditional raw materials with environmentally-friendly materials, technologies, in the course of which we must emphasize the increasing importance of biotechnology (R2: Replacement). Biotechnology products, such as special yeasts and bacteria used in oenology, were developed (among other reasons) in order to decrease the amount of used water or agro-chemical materials through their use, thus making viticulture, oenology more sustainable.

Concerning packaging, alternative solutions need to be mentioned, such as bag in a box or aluminium cans used in oenology, for example. These applications also yield a better utilization of transport capacities and, as a result, less environmental burden.

In the case of every industry supply chain, of course, the targeted market segments also need to be considered; it is obvious that flagship wines of exceptional quality 
will not be filled in a bag in a box. In the case of the pharmaceutical industry although using multimodal transport would be a more environmentally-friendly solution in many cases -, public road transport is used primarily due to special consumer needs.

The supply chains of food industry, e.g., refrigeration companies, were analysed with special regard for green logistics (LOGÓ et al. 2016: 115-137). With the principles of sustainable development spreading more and more, these perspectives receive an increased level of attention in food supply chains as well. Eco-cultivation methods, increasing the proportion of combined transport with the involvement of transport branches polluting the environment less, zero waste generation factories, and a $-20 \%$ decrease in energy consumption by 2020 all contribute to decreasing $\mathrm{CO}_{2}$ emission.

Compliance with consumer expectations is the focus of quality and logistics as well; also, they became equal factors with regard to aspects defining the competitiveness of products and services (price, quantity, delivery accuracy, selection, product-related services).

Concerning packaging, this topic includes using intermediate cardboard from recycled paper, recycled stretch, and shrink film.

The third and last preceding task is reusing materials (R3: Reusing), in the context of which reusable packaging material is a typical example. Such packaging materials can be glass wine bottles, plastic racks, plastic cans, and pallets. Using this method makes the existing logistics system significantly more complex since 'the traditionally unidirectional system must be made two-directional' (Mike 2002). The GLN (indicating organizations, legal entities) and GTIN (indicating, for example, products or reused packaging material) numbers to be presented later will have a truly great significance in the case of reused packaging material. With the help of these numbers not only the companies but the individual products and their packaging materials will also become identifiable and traceable.

The posterior task of reverse logistics is the processing, recycling of materials (R4: Recycling). In this case, the product loses its original function, and the goal of the process is to reclaim the still usable materials. If the reclaimed material is of appropriate quality, then it can be used for the production of the original parts as well. Processing can be done with several methods, a common characteristic of which is that they require using a significant amount of resources; however, this amount is still less than what producing the original raw material would require (Réger 2010: 63-68). 


\section{Materials and Methods}

\section{Our Data, Sample Analysis}

Our analysis is based on data recorded from an online questionnaire carried out between 29 October and 17 November 2017. In the survey, we studied the logistics models of 55 companies in Hungary. The respondents were the heads of the logistics departments in the case of multinational (MNC - Multinational Corporation), large and medium-sized companies and the company managers in the case of small enterprises.

Considering the years of foundation of the companies, most of them were established between 1990 and 2005, and in a smaller proportion there were a few with a long history and some others that can be considered young.

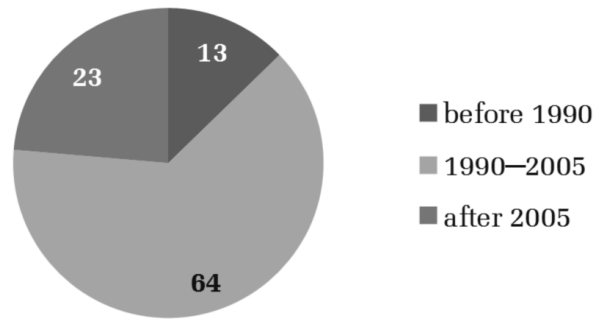

Source: own edition

Figure 1. Year of foundation of companies $(N=55)$

Almost two-thirds (64\%) of the companies were founded between 1990 and $2005,23 \%$ of them were founded after 2005 , and the smallest group is that of the companies established before 1990, with 13\%, as Fig. 1 shows it.

Considering their activity in the industry, illustrated in Fig. 2, almost all branches of industry are represented; representatives of companies with highly diverse activities filled in the questionnaire. However, services and the food industry are dominantly present. These together represent a total of $44 \% .7 \%$ of the interviewed companies perform chemical and $5 \%$ of them perform building industry activities. The proportion of companies performing engineering and light industry activities is $4 \%$ each. One company is represented from each of the following areas: defence, healthcare, pharmaceutical industry, and automobile industry - indicated as activities in other branches of industry. 


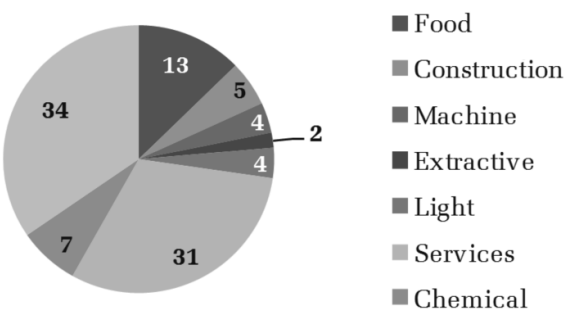

Figure 2. Industry $(N=55)$

Source: own edition

Table 1 summarizes the distribution of companies according to the number of employees. In this regard, the large companies (51\%) and SME sector companies $(42 \%)$ are represented in almost the same proportion. The proportion of micro companies is $7 \%$.

Table 1. Number of employees $(N=55)$

\begin{tabular}{cc}
\hline Number of employees & Number of companies (\%) \\
\hline $0-9$ & 7 \\
\hline $10-49$ & 18 \\
\hline $50-249$ & 24 \\
\hline Over 250 & 51 \\
\hline Total & 100 \\
\hline
\end{tabular}

Source: own edition

The distribution of the companies in the sample according to the revenue can be seen from the data presented in Table 2. Companies with a smaller revenue had lesser weight; the proportion of respondents with a yearly revenue under 600 million forints is $18 \%$. The proportion of companies with high revenue (above 15 million forints) can be considered significant with $40 \%$.

Table 2. Revenue of the companies $(N=55)$

\begin{tabular}{cc}
\hline Revenue (million forints) & Proportion of companies (\%) \\
\hline$<600$ & 18 \\
\hline $600-3,000$ & 16 \\
\hline $3,000-15,000$ & 25 \\
\hline$>15,000$ & 40 \\
\hline Total & 100 \\
\hline
\end{tabular}

Source: own edition

Positions on the corporate supply chain are shown in Table 3 . The three definitive positions are: logistics service provider, dominant producer company, and tier 1 supplier. 
Table 3. Position in the supply chain $(N=55)$

\begin{tabular}{lc}
\hline Position held & Proportion of companies \\
\hline Logistics service provider & 34 \\
\hline Retailer & 11 \\
\hline Wholesale trader & 16 \\
\hline Dominant producer company & 29 \\
\hline Tier 1 supplier of the central company & 25 \\
\hline Tier 2 supplier of the central company & 5 \\
\hline Tier 3 supplier of the central company & 2 \\
\hline Other & 11 \\
\hline
\end{tabular}

The distribution of the headquarters of the companies involved in our sample: it can be seen that the dominant majority of the companies in the survey have their headquarters either in Hungary (61.8\%) or in Germany (20\%). Additionally, companies with headquarters in Europe are represented in the sample with $91 \%$, while companies with headquarters in North America and Asia amount only to 5.5\% and $3.5 \%$ respectively. From all this, it follows that our data can primarily be used to compare company headquarters in Europe and domestic company headquarters; the present set of data is not suitable for breakdown concerning other continents.

\section{Results and Discussions}

\section{Sustainable Logistics as Reflected by Our Data}

In our article, we seek the answer to the correlations of the theoretical path model as described below (Székelyi-Barna 2002, Loehlin-Beaujean 2016, Latan-Noonan 2017) (Fig. 3). In our model, we study the boundary conditions strengthening the establishment of sustainable logistics models (4R) in the context of Hungarian companies. However, sustainable logistics has a role not only as a dependent variable but as an intermediary variable as well since in our model we pay attention to the analysis of those positive mechanisms of action that might appear in the life of companies as the result of introducing the $4 \mathrm{R}$. 


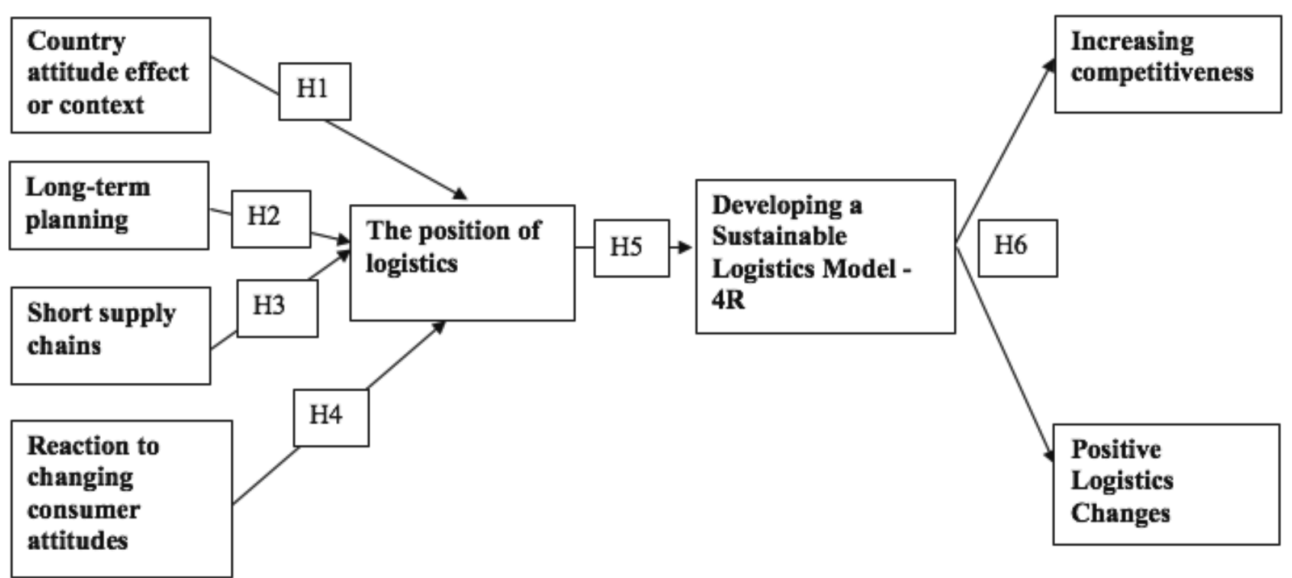

Figure 3. Theoretical path model of the $4 R$ of companies in Hungary

In our model, we measure the level of logistics within the companies with the help of 4 explanatory variables; these are what we connected our first four hypotheses and the correlations (direct and indirect) between the variables to, indicated by the direction of arrows:

- We named our first variable Country attitude effect. By this explanatory variable we mean the effect of the context, that is, to what extent a given company follows the international trends in its company culture. This has special importance because the ecology-based company management concept and the adaptation of the sustainable logistics model are increasingly widespread in international company management. As a result, in our first hypothesis (H1), we assume that a difference can be found between companies operating in Hungary based on whether it is a company founded in Hungary or abroad. This is because we assume that, influenced by the international context, logistics receives a stronger role within the company, and the realization of the sustainable logistics model is more widespread.

- Our second explanatory variable received the name Long-term planning; it means that a correlation can be proven between long-term planning (more characteristic of larger companies) and the implementation of the sustainable logistics model. As the result of all that, in our second hypothesis (H2) we assume that a positive correlation can be found between company size (and, together with that, the longterm planning model) and the establishment of a sustainable logistics model.

- Our third explanatory variable in the model is named Short supply chains (SSC), based on which we assume (H3) that a positive move towards the establishment of a sustainable logistics model can be found among companies that build their logistics on short supply chains.

- Finally, as a fourth explanatory variable, we included Reaction to changes in consumer attitude in our path model. In this regard, we focus on the rapid changes in 
consumer attitude - as known from the international literature -, as a consequence of which more aware consumer attitude and buying ecological, more sustainable products and services became one of the most important consumer priorities in the past years. Consequently, in our $4^{\text {th }}$ hypothesis (H4), we assume that companies that pay attention to changes in consumer attitude will create a more sustainable logistics model in their everyday operation.

As an intermediate variable in our path model, we present the strategic role of $\operatorname{logistics}^{2}$ within the company and the establishment of sustainable logistics (4R) within the companies. With all that, in our fifth hypothesis (H5), we assume that there is a close correlation between the integrated as well as strategic role of the logistics department within the companies and implementing the sustainable logistics model.

In our model, we also discuss and study the effects of the $4 \mathrm{R}$ (H6), in which we analyse that in the case of companies the introduction of the sustainable logistics model implies such positive mechanisms of action as a consequence of which their competitiveness increases on the one hand and the quality of company logistics is improved on the other.

\section{Creating the Variables of Our Path Model}

Actually, in our path model, we want nothing else than divide the zero-order linear correlation between our independent variables (exogenous variables) and dependent variables into parts. As a consequence, in the following section, we discuss the method of creating our variables.

We created our variables in our path model with different dimension-reducing processes (factor analysis, main component analysis, cluster analysis). However, a couple of our explanatory variables, such as the country attitude variable, were not prepared with these dimension-reducing procedures.

From the variable of headquarters, we could create our country attitude explanatory variable by dummying. In the course of variable transformation, we separated companies with headquarters in Hungary from companies with headquarters outside Hungary ('international'). By this, we created one of the explanatory variables of sustainable logistics, that is, whether the company in question is a subsidiary of an international company group, as a result of which the effects following international trends of sustainability have a stronger influence on them, or how true this statement is in the case of non-subsidiary companies with domestic headquarters on which the international tendencies have much less effect.

2 In our first model, logistics within the company was an initial explanatory variable; however, based on our primary calculations (Pearson's correlations, regression analyses), it became obvious that presenting logistics applied within the company as an intermediary variable is more obvious in our model in the Hungarian context. 
The descriptive statistics of the country attitude explanatory variable are summarized in the table below.

Table 4. Distribution of the country attitude explanatory variable

\begin{tabular}{llcccc}
\hline & Frequency & Percentage & $\begin{array}{c}\text { Valid } \\
\text { Percentage }\end{array}$ & $\begin{array}{c}\text { Cumulative } \\
\text { Percentage }\end{array}$ \\
\hline \multirow{3}{*}{ Valid } & International & 21 & 38.2 & 38.2 & 38.2 \\
\cline { 2 - 6 } & Hungarian & 34 & 61.8 & 61.8 & 100.0 \\
\cline { 2 - 6 } & Total & 55 & 100.0 & 100.0 & \\
\hline
\end{tabular}

Based on the above table, it can be seen that in our sample Hungarian nonsubsidiaries are the majority (61.8\%); however, foreign subsidiaries operating in Hungary have an appropriate percentage $(38.2 \%)$ to verify our hypothesis.

We created our explanatory variable named long-term planning with factor analysis, from 4 different variables. The four variables took stock of the number of premises and employees, the size of the revenue of the company, and the year of the foundation of the company. ${ }^{3}$ In the course of the factor analysis, we created 3 factors, with 5 iterations and immediate rotation. The commonality of all 4 variables had a value higher than 0.25 . The entire explained proportion of the factor structure made up $95 \%$ of the explanatory value of the total variable set. Therefore, the factor structure has a very strong explanatory force. Based on the factor weights of the rotated factor structure, we could create three well-distinguishable factors, which are the following:

Table 5. Factors with their factor scores

\begin{tabular}{|c|c|c|}
\hline $\begin{array}{c}\text { MNC } \\
1^{\text {st }} \text { factor }\end{array}$ & $\begin{array}{c}\text { Large company } \\
2^{\text {nd }} \text { factor }\end{array}$ & $\begin{array}{c}\text { SME } \\
3^{\text {rd }} \text { factor }\end{array}$ \\
\hline $\begin{array}{l}\text { Have a medium amount } \\
\text { of premises (.077) }\end{array}$ & $\begin{array}{l}\text { Have many premises } \\
(.955)\end{array}$ & $\begin{array}{l}\text { Have few premises } \\
(-.283)\end{array}$ \\
\hline $\begin{array}{l}\text { Many employees } \\
(.951)\end{array}$ & $\begin{array}{l}\text { Medium amount of } \\
\text { employees (.105) }\end{array}$ & $\begin{array}{l}\text { Few employees } \\
(-.058)\end{array}$ \\
\hline High revenue (.914) & Medium revenue (.033) & Low revenue $(-.256)$ \\
\hline Older $(-.202)$ & Older (-.317) & New company (.923) \\
\hline
\end{tabular}

3 The KMO value of the analysis is 0.559 , which means that the correlation between the variables can be analysed by factor generation; moreover, an exceptionally strong co-variance can be demonstrated between the variables. The significance level belonging to the Bartlett test is 0.000 , based on which we can deny the null hypothesis of the Bartlett test, and it can be established that the elements of the correlation matrix outside the main diagonal are not different from zero, only accidentally. In other words, the matrix of variables is significantly different from the identity matrix. 
The first factor symbolizes the company type, which is a company that has been operating for a relatively long time, with a medium amount of premises, many employees, and with high revenue. As a result, we named the first factor MNC (Multinational Corporation). Companies belonging to the second factor have many premises, a medium number of employees, and medium revenue but were incorporated a longer time ago, so this factor was given the name Large company. Finally, companies in the third factor are characterized by having only a few premises, few employees, and low revenue - they were named SMEs.

However, since our primary goal was not to separate company sizes but to specify planning horizons, when creating the factors, we tested our factors with linear regressions, in the course of which we assumed that different planning horizons are attached to companies in the 3 factors. In our models, we inserted the futureoriented planning of companies in three regression models along the factors and assumed that while large companies and MNCs focus on long-term planning - as a consequence of their economies of scale, employee numbers, and revenue the SMEs rather have short-term planning as a dominant strategy. Results of our regression analyses verified our assumptions. That is, the beta values of the three regression analyses were in accordance with our previous expectations. According to our results, long-term planning is the least characteristic of the companies in the SME factor (Standardized Regression Beta $=-0.23$ ), followed by companies in the first factor, that is, MNCs (Stand. Reg. Beta = 0.008), and long-term planning is the most important for large companies in the $2^{\text {nd }}$ factor (Stand. Reg. Beta $=0.83$ ).

We also prepared our next explanatory variable, the short supply chain variable, with factor analysis. ${ }^{4}$ We involved variables in the factor analysis measuring the close relationship between the company, the customers, and the suppliers. We analysed variables, gathering information that observe the presence of small distance between producer and consumer, small scale, and small volume of production. As a result of all the above, two well-distinguishable factors were created, making up $54 \%$ of the explanatory value of the total variable set. Based on the factor structure, two types of dominant and different supply chain structures could be very well distinguished, in which one had SSC type supply strategies, and the other one had non-SSC type strategies. Later in our analysis, we obviously included the factor applying the SSC type strategy. ${ }^{5}$

In the first round, we created our explanatory variable measuring the reaction to changes in consumer attitude by dummying, measuring intercompany strategic connections on the consumer and supplier side. As a result, we could measure

4 The KMO value of the factor analysis is 0.658 , which means that the correlation between the variables can be analysed by factor generation. The significance level belonging to the Bartlett test is 0.000 .

5 In the course of our analysis, we prepared another, separate dummy variable measuring SSC strategy, focusing in particular on retailers; however, we later left this variable out of our model because its use did not lead to significant results. 
the reaction to consumer attitude in the breakdown by branches of industry, in consumer relations, and through company connections alike. Later, we condensed these 2 dummy variables into 1 variable named consumer attitude.

Moving on to intermediary variables, for analysing our path model, it became a priority to create a variable that measures the strategic role of logistics itself within the companies. We created this variable by main component analysis, and in this variable we condensed to what extent a company manages logistics in a systemlevel approach, whether or not the company uses integrated company management system, and how logistical functions are treated in priority roles within the company.

We created our variable observing the main issues in our article, that is, the variable measuring sustainable logistics (4R) with the help of cluster analysis. In the course of the cluster analysis, the 4 separate sustainable logistics segments (1R - Reduction at the source, 2R - Replacement, 3R - Reusing, and 4R - Recycling) were classified into two very well-distinguishable clusters in the case of companies included in our sample. We prepared the cluster structure by K-means clustering procedure, in the course of which the program got to the final cluster structure after 2 iterations. ${ }^{6}$ As a consequence of the 2 iterations, we received a stable cluster structure, in which the first cluster included 32 companies and the second one 23 companies.

The 2 clusters represent two different sustainable logistics strategies; the first cluster characterizes companies implementing $2 \mathrm{R}$ and $4 \mathrm{R}$ logistics, that is, they are primarily replacing traditional raw materials with environmentally-friendly materials and technologies (2R) and perform the recycling of materials. Meanwhile, in the second cluster, those companies are represented that follow $1 \mathrm{R}$ and $3 \mathrm{R}$ logistics, by decreasing the proportion, amount of raw materials (1R), and reused materials (3R).

In our path model, we included the possible consequences of implementing $4 \mathrm{R}$ as well, for the measurement of which we created two variables. First, the increasing competitiveness was created by main component analysis, from the variables that measured return on sales, return on equity, market share, and the increase in the quality of products/services. Finally, we created our factor measuring the increase in the quality of logistics by main component analysis; in this, we condensed increase in the quality and quantity of the accuracy of promised deliveries, invoice accuracy, and the increase in the quality of logistics services.

6 The ANOVA table belonging to the analysis says that our model is significant since every F-test belonging to our one-way variance analysis ran for each cluster-generating variable is significant, that is, cluster centres are significantly different. Furthermore, unexplained parts are small in the single cluster variables. 


\section{Path Models of Sustainable Logistics}

From the above set of variables, it can be seen that in our sample the $4 \mathrm{R}$-based logistics can be basically divided into two clusters: a cluster of companies using $2 \mathrm{R}$ and $4 \mathrm{R}$ and a cluster modelling companies using $1 \mathrm{R}$ and $3 \mathrm{R}$. As a consequence, in our analysis, we prepared two path models accordingly. Our first path model is the path model of companies using 2R and 4R (Fig. 4).

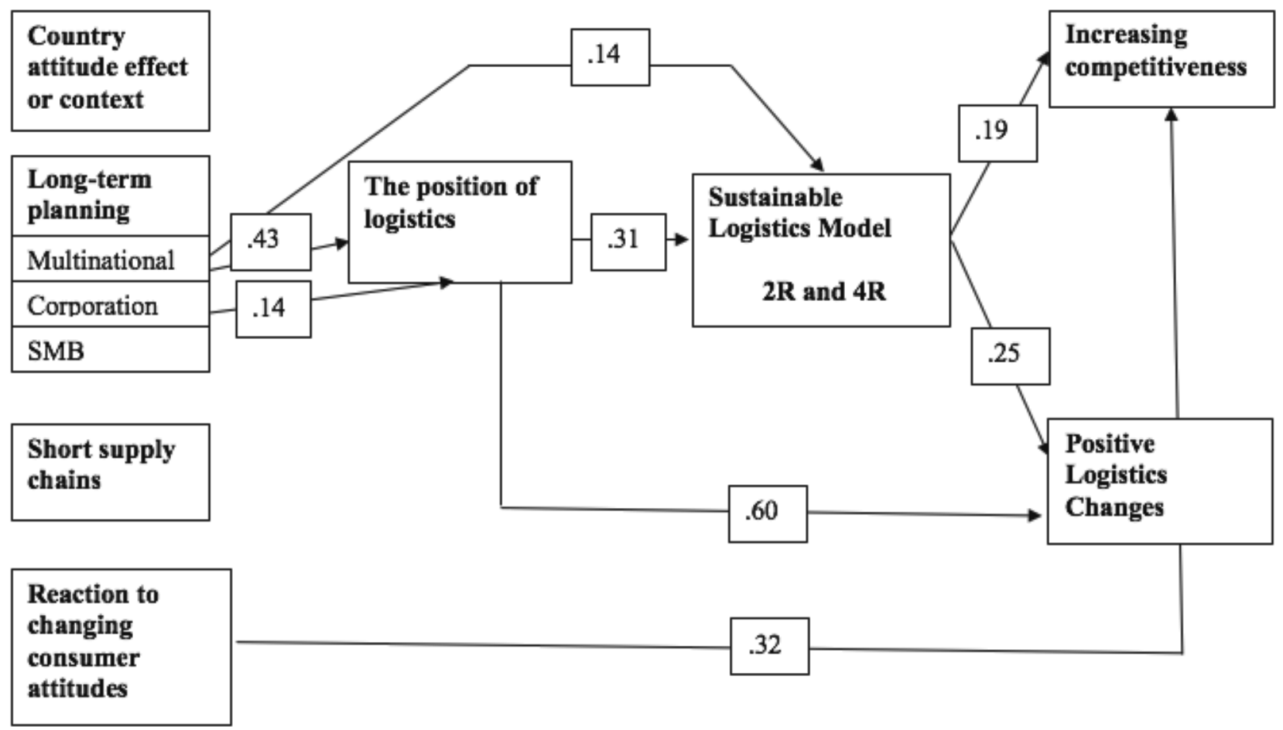

Figure 4. Path model for companies implementing $2 R$ to $4 R$

In the path model based on the standardized beta of regression coefficients, it can be seen what causal correlations are revealed in the case of sustainable logistics. Based on the significances of the t-test, it can be clearly seen (Table 6) that the country-level attitude variable, the SME factor, the short supply chains factor, and the reaction to changes in consumer attitude have no significant role in creating a logistics department within a company; ${ }^{7}$ therefore, we deleted these arrows from our model. At the same time, in the case of long-term planning, the strategic role of logistics has a priority status (.43), while it also plays a role in the case of large companies, although not to the same extent (.14).

$7 \quad$ F-statistics belonging to the regression analysis are always significant; therefore, we will not present these in our article. 
Table 6. Coefficients

\begin{tabular}{|c|c|c|c|c|c|c|}
\hline \multicolumn{2}{|c|}{ Model } & \multicolumn{2}{|c|}{$\begin{array}{l}\text { Unstandardized } \\
\text { Coefficients }\end{array}$} & \multirow{2}{*}{$\begin{array}{c}\begin{array}{c}\text { Standardized } \\
\text { Coefficients }\end{array} \\
\text { Beta }\end{array}$} & \multirow[t]{2}{*}{$\mathrm{t}$} & \multirow[t]{2}{*}{ Sig. } \\
\hline & & $\mathrm{B}$ & Std. Error & & & \\
\hline \multirow{7}{*}{1} & (Constant) & -.093 & .494 & & -.188 & .852 \\
\hline & Country attitude & -.355 & .287 & -.174 & -1.239 & .222 \\
\hline & MNC Factor & .428 & .137 & .428 & 3.126 & .003 \\
\hline & Large Company Factor & .140 & .128 & .140 & 1.090 & .007 \\
\hline & SME_Factor & -.075 & .130 & -.075 & -.579 & .565 \\
\hline & SSC_Factor & -.022 & .134 & -.022 & -.166 & .869 \\
\hline & $\begin{array}{l}\text { Reaction to changes in } \\
\text { consumer attitude }\end{array}$ & .343 & .458 & .100 & .750 & .457 \\
\hline
\end{tabular}

If we look at the direct effects of our explanatory variables (Table 6 ) in the case of $2 \mathrm{R}$ and $4 \mathrm{R}$, then we get the following table containing regression betas. Based on this, it can be seen that we get significant values for $2 \mathrm{R}$ and $4 \mathrm{R}$ in the case of MNCs only; however, in their case, we can measure a very important effect in the area of green logistics (.14).

Table 7. Coefficients ${ }^{a}$

\begin{tabular}{|c|c|c|c|c|c|c|}
\hline \multirow{2}{*}{\multicolumn{2}{|c|}{ Model }} & \multicolumn{2}{|c|}{$\begin{array}{l}\text { Unstandardized } \\
\text { Coefficients }\end{array}$} & \multirow{2}{*}{$\begin{array}{c}\text { Standardized } \\
\text { Coefficients } \\
\text { Beta } \\
\end{array}$} & \multirow[t]{2}{*}{$\mathrm{t}$} & \multirow[t]{2}{*}{ Sig. } \\
\hline & & $\mathrm{B}$ & Std. Error & & & \\
\hline \multirow{7}{*}{1} & (Constant) & 1.108 & .215 & & 5.162 & .000 \\
\hline & Country attitude & -.156 & .125 & -.189 & -1.249 & .218 \\
\hline & MNC Factor & .112 & .059 & .142 & 1.670 & .012 \\
\hline & Large Company & .000 & .056 & .000 & .002 & .998 \\
\hline & SME & -.007 & .056 & -.018 & -.128 & .899 \\
\hline & SSC & .056 & .058 & .138 & .956 & .344 \\
\hline & $\begin{array}{l}\text { Reaction to changes in } \\
\text { consumer attitude }\end{array}$ & -.233 & .199 & -.167 & -1.170 & .248 \\
\hline
\end{tabular}

In Table 7 , from the intermediary variables, it can be seen that a significant and strong correlation can be demonstrated between the role of logistics and the implementation of $2 \mathrm{R}$ and $4 \mathrm{R}(.31)$. 
Table 8. Coefficients ${ }^{a}$

\begin{tabular}{|c|c|c|c|c|c|c|}
\hline \multirow{2}{*}{\multicolumn{2}{|c|}{ Model }} & \multicolumn{2}{|c|}{$\begin{array}{l}\text { Unstandardized } \\
\text { Coefficients }\end{array}$} & \multirow{2}{*}{$\begin{array}{c}\text { Standardized } \\
\text { Coefficients }\end{array}$} & \multirow[t]{2}{*}{$\mathrm{t}$} & \multirow[t]{2}{*}{ Sig. } \\
\hline & & $\mathrm{B}$ & Std. Error & & & \\
\hline \multirow{2}{*}{1} & (Constant) & .800 & .052 & & 15.349 & .000 \\
\hline & Logistics Factor & .310 & .053 & .316 & 2.428 & .019 \\
\hline
\end{tabular}

a. Dependent variables: 2R - Replacement; 4R - Recycling

Moving on to the positive effects of $2 \mathrm{R}$ and $4 \mathrm{R}$, we can see (Table 8 ) that it has a significant effect on both increasing competitiveness (.19) and strengthening logistics (.25). However, reaction to consumer attitudes also has a very strong direct effect on competitiveness (.32), and, obviously, the strategic role of company logistics also has a special, direct, and very strong effect in improving the quality of logistics (.60).

Table 9. Coefficients ${ }^{a}$

\begin{tabular}{|c|c|c|c|c|c|c|}
\hline \multirow{2}{*}{\multicolumn{2}{|c|}{ Model }} & \multicolumn{2}{|c|}{$\begin{array}{l}\text { Unstandardized } \\
\text { Coefficients }\end{array}$} & \multirow{2}{*}{$\begin{array}{c}\begin{array}{c}\text { Standardized } \\
\text { Coefficients }\end{array} \\
\text { Beta }\end{array}$} & \multirow[t]{2}{*}{$\mathrm{t}$} & \multirow[t]{2}{*}{ Sig. } \\
\hline & & $\mathrm{B}$ & Std. Error & & & \\
\hline \multirow{2}{*}{1} & (Constant) & -.015 & .304 & & -.050 & .000 \\
\hline & $2 \mathrm{R}$ and $4 \mathrm{R}$ & .190 & .340 & .120 & .056 & .008 \\
\hline
\end{tabular}

a. Dependent variable: competitiveness factor

Table 10. Coefficients ${ }^{a}$

\begin{tabular}{|c|c|c|c|c|c|c|}
\hline \multirow{2}{*}{\multicolumn{2}{|c|}{ Model }} & \multicolumn{2}{|c|}{$\begin{array}{l}\text { Unstandardized } \\
\text { Coefficients }\end{array}$} & \multirow{2}{*}{$\begin{array}{c}\text { Standardized } \\
\text { Coefficients } \\
\text { Beta }\end{array}$} & \multirow[t]{2}{*}{$\mathrm{t}$} & \multirow[t]{2}{*}{ Sig. } \\
\hline & & $\mathrm{B}$ & Std. Error & & & \\
\hline \multirow{2}{*}{1} & (Constant) & -.201 & .303 & & -.665 & .000 \\
\hline & $2 \mathrm{R}$ and $4 \mathrm{R}$ & .252 & .339 & .102 & .743 & .006 \\
\hline
\end{tabular}

a. Dependent variable: logistical quality factor

In summary, therefore, it can be established that from sustainable logistics replacement of traditional raw materials and recycling ( $2 R$ and $4 R$ ) mostly appears in the case of companies where special attention is paid to the establishment of the strategic role of logistics within a company. These companies are primarily companies interested in long-term planning, that is, MNCs and large companies. Additionally, $2 \mathrm{R}$ and $4 \mathrm{R}$ have a decisive role in increasing the competitiveness of companies and improving the quality of logistics as well.

In our second path model (Fig. 5), we analyse the two other fields of sustainable logistics, that is, the causal correlations of sustainable logistics segments related to reducing the proportion, amount of raw materials (1R) and reusing materials (3R). 


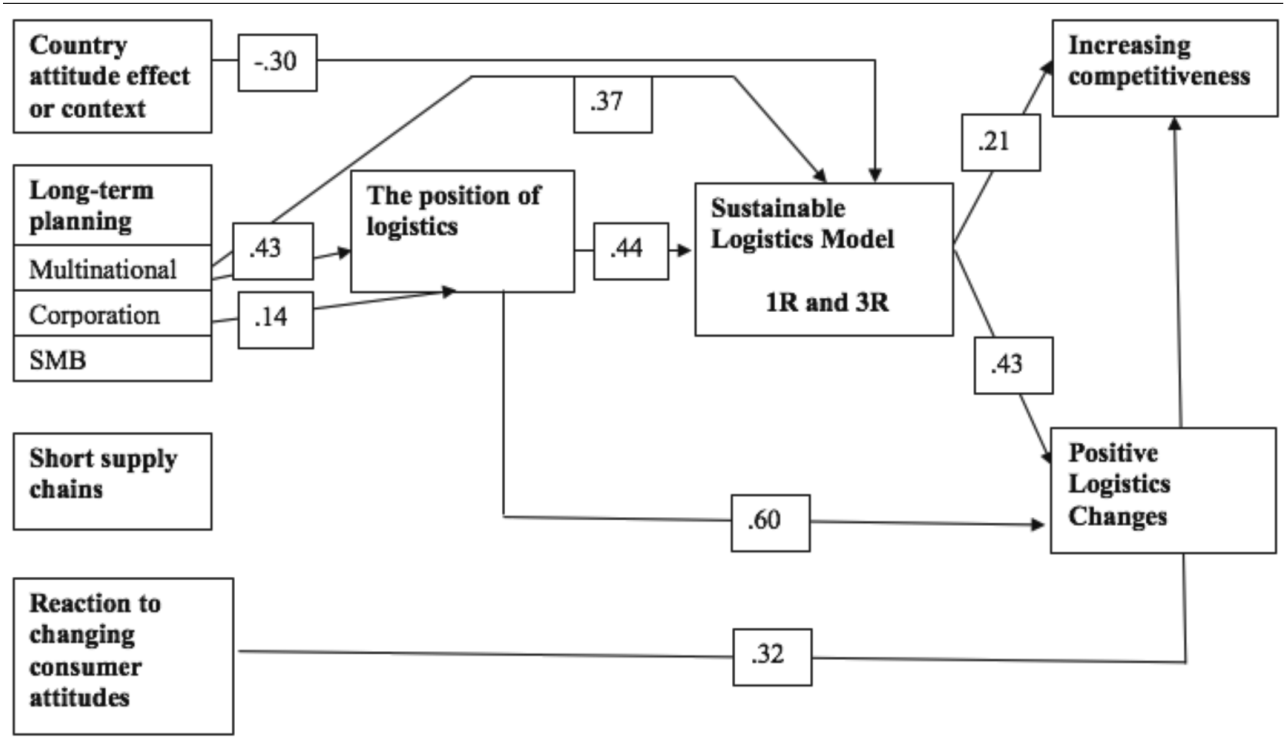

Figure 5. Path model for companies implementing $1 R$ to $3 R$

Obviously, compared to our previous path model, in the case of our second path model, we often do not find changes in the case of regression betas; so, henceforth, we only focus on the parts that have changed compared to our previous model.

First, it can be clearly seen that in the present model the role of the strategic position of logistics within the company (Table 9) has further increased (.44).

Furthermore, the direct effect of the MNC factor increased in the field of introducing sustainable logistics $1 \mathrm{R}$ and 3R (Table 10).

Table 11. Coefficients ${ }^{a}$

\begin{tabular}{|c|c|c|c|c|c|c|}
\hline \multirow{2}{*}{\multicolumn{2}{|c|}{ Model }} & \multicolumn{2}{|c|}{$\begin{array}{l}\text { Unstandardized } \\
\text { Coefficients }\end{array}$} & \multirow{2}{*}{$\begin{array}{c}\begin{array}{c}\text { Standardized } \\
\text { Coefficients }\end{array} \\
\text { Beta }\end{array}$} & \multirow[t]{2}{*}{$\mathrm{t}$} & \multirow[t]{2}{*}{ Sig. } \\
\hline & & B & Std. Error & & & \\
\hline \multirow[b]{2}{*}{1} & (Constant) & .873 & .041 & & 21.228 & .000 \\
\hline & $\begin{array}{l}\text { Logistics within the } \\
\text { company factor }\end{array}$ & .148 & .041 & .440 & 3.566 & .001 \\
\hline
\end{tabular}

Table 12. Coefficients ${ }^{a}$

\begin{tabular}{llrrrrr}
\hline \multirow{2}{*}{ Model } & \multicolumn{2}{c}{$\begin{array}{c}\text { Unstandardized } \\
\text { Coefficients }\end{array}$} & $\begin{array}{c}\text { Standardized } \\
\text { Coefficients }\end{array}$ & t & \multirow{2}{*}{ Sig. } \\
\cline { 2 - 5 } & \multicolumn{2}{c}{ B } & Std. Error & Beta & & \\
\hline \multirow{2}{*}{1} & (Constant) & .873 & .043 & & 20.515 & .000 \\
\cline { 2 - 7 } & MNC Factor & .359 & .043 & .369 & 2.895 & .006 \\
\hline
\end{tabular}

a. Dependent variables: 1R - Reduction at the source; 3R - Reusing 
It is an interesting development that in this path model the country attitude variable already has a significant and prioritized (-.30), direct role in the case of sustainable logistics implementing $1 \mathrm{R}$ and $3 \mathrm{R}$ (Table 11). This means that the international company context, that is, whether the company follows international logistics trends or not, has a strong effect.

Table 13. Coefficients ${ }^{a}$

\begin{tabular}{|c|c|c|c|c|c|c|}
\hline \multirow{2}{*}{\multicolumn{2}{|c|}{ Model }} & \multicolumn{2}{|c|}{$\begin{array}{c}\text { Unstandardized } \\
\text { Coefficients } \\
\end{array}$} & \multirow{2}{*}{$\begin{array}{c}\text { Standardized } \\
\text { Coefficients }\end{array}$} & \multirow[t]{2}{*}{$\mathrm{t}$} & \multirow[t]{2}{*}{ Sig. } \\
\hline & & $\mathrm{B}$ & Std. Error & & & \\
\hline \multirow{7}{*}{1} & (Constant) & 1.066 & .180 & & 5.933 & .000 \\
\hline & Country attitude & -.234 & .104 & -.301 & -1.268 & .014 \\
\hline & MNC Factor & .122 & .050 & .372 & 1.896 & .003 \\
\hline & Large company & .002 & .047 & .006 & .042 & .967 \\
\hline & SME & -.008 & .047 & -.023 & -.165 & .869 \\
\hline & SSC & .011 & .049 & .034 & .234 & .816 \\
\hline & $\begin{array}{l}\text { Reaction to changes in } \\
\text { consumer attitude }\end{array}$ & -.123 & .167 & -.106 & -.735 & .466 \\
\hline
\end{tabular}

Segments $1 \mathrm{R}$ and $3 \mathrm{R}$ of sustainable logistics additionally have a stronger effect on increasing competitiveness and developing the quality of logistics than their counterparts $2 \mathrm{R}$ and $4 \mathrm{R}(.21$ and .43).

In summary, therefore, we can see that concerning those areas of sustainable logistics that include reducing the amount of raw materials (1R) and reusing raw materials (3R) the effect of the international context becomes significantly stronger, and the strategic role of logistics increases. As a consequence, these elements have a stronger effect on increasing competitiveness and improving the quality of logistics.

\section{Conclusions}

In our article, we intended to find out what factors influence the sustainable logistics segments classified in $4 \mathrm{R}$ in the case of companies in Hungary and what effects the introduction of these sustainable segments can have on companies.

We tested our hypothesis based on two path models. The two path models were needed because it can be seen that companies in Hungary usually use two segments of the 4 Rs. They either use $2 \mathrm{R}$ and $4 \mathrm{R}$ or $1 \mathrm{R}$ and $3 \mathrm{R}$. Based on our analyses, we could verify most of our hypotheses.

In our first hypothesis (H1), we assumed that among the subsidiaries operating in Hungary the strategic role of logistics is stronger as the effect of the foreign context 
and the implementation of the sustainable logistics model is more widespread. We have to discard this hypothesis in part. Based on our analyses, we did not find significant correlation between contexts construed along different countries and the strategic role of logistics. However, international context has a significant role in the case of Hungarian companies implementing $1 \mathrm{R}$ and $3 \mathrm{R}$.

In our second hypothesis (H2), we assumed that a positive correlation can be demonstrated between company size (and, together with that, the long-term planning model) and the establishment of a sustainable logistics model. We verified this hypothesis since in the case of both the large companies and the MNCs the establishment of the strategic role of the logistics system has a central role. Furthermore, in the case of the MNCs, the positive correlation can be observed as a direct effect alongside logistics implementing $2 \mathrm{R}$ and $4 \mathrm{R}$ as well as logistics implementing $1 \mathrm{R}$ and $3 \mathrm{R}$.

In our third hypothesis (H3), we assumed that among companies that build their logistics on short supply chains a change in the positive direction can be demonstrated towards the establishment of the sustainable logistics model. Our analysis refuted this hypothesis.

In our fourth hypothesis (H4), we assumed that companies that consider changes in consumer attitude create a more sustainable logistics model in their everyday operation. In our analysis, we had to refute this hypothesis too because such a correlation cannot be demonstrated based on our data. However, the quick reaction to changes in consumer attitude results in a significant increase in competitiveness, without implementing sustainable logistics.

In our fifth hypothesis (H5), we assumed that a close correlation can be demonstrated between the priority implementation of logistics within the companies and implementing the sustainable logistics model. We verified this hypothesis. In the case of both the companies implementing 2 and $4 \mathrm{R}$ and the ones implementing 1 and 3R, the appearance of the strategic logistics department within the companies has a priority role in establishing sustainable logistics.

Finally, in our sixth hypothesis (H6), we analysed the effects of $4 \mathrm{R}$. This hypothesis also turned out to be correct. Sustainable logistics segments have a role in both increasing competitiveness and in improving the quality of logistics.

In summary, based on the data of our sample, the application of reverse logistics model is not uniform in Hungarian companies. It is likely that some companies mostly focus on 2R and 4R (R2: Replacement and R4: Recycling) and others focus mainly on $1 \mathrm{R}$ and $3 \mathrm{R}$ (R1: Reduction at the source and R3: Reusing).

It can be seen that the establishment of the logistics unit and its strategic role within the company has a large significance in the case of both groups and the MNC or large company framework, that is, companies performing long-term planning act as a decisive factor in both groups. The context effect of the company has a role only in the case of companies realizing $1 R$ and $3 R$. In addition to that, we 
did not find any correlation between short supply chains, reactions to changes in consumer attitude, and establishing reverse logistics. However, it can be measured that the introduction of $4 \mathrm{R}$ has a strong effect on increasing the competitiveness of the company and on improving the quality of the logistics service.

We consider it important to note that in our research we did not measure the issue of cost-reducing measures of the companies, which we assume that can also have a correlation to the implementation of sustainable logistics; however, supporting this hypothesis requires further research. We also consider the longitudinal analysis of operators in the logistics service sector and of companies using logistics services along the above criteria as additional potential research directions.

\section{References}

CARTER, R. Craig-EASTON, P. Liane. 2011. Sustainable Supply Chain Management: Evolution and Future Directions. International Journal of Physical Distribution $\mathcal{E}$ Logistics Management 41(1): 46-62.

CHRISTOPHER, Martin. 1992. Logistics and Supply Chain Management. London: Pitman Publishing.

CIGOLINI, Roberto-COZZI, Marco-PERONA Marco. 2004. A New Framework for Supply Chain Management. Conceptual Model and Empirical Test. International Journal of Operations and Production Management 24: 7-41.

DÉRI, András-VÁNDORFFY, István. 2005. A „,bővített” ellátási lánc. In: Logisztikai Évkönyv. Budapest: Magyar Logisztikai Egyesület. 50-58.

EMMETT, Stuart-SOOD, Vivek. 2010. Green Supply Chains: An Action Manifesto. Carnwall, UK: Wiley.

FORMENTINI, Marco-TATICCHI, Paolo. 2016. Corporate Sustainability Approaches and Governance Mechanisms in Sustainable Supply Chain Management. Journal of Cleaner Production 112: 1920-1933.

HARANGOZÓ, Gábor. 2016. A karbon lábnyom koncepció szerepe a vállalkozásfejlesztésben. $\quad$ http://kgk.uni-obuda.hu/sites/default/files/11_ Harangozo-Gabor.pdf. 129-146.

HARANGOZÓ, Gábor-CSUTORA, Mária-TÁTRAI, Tünde-VÖRÖSMARTY, Gyöngyi. 2019. A zöld ellátásilánc-menedzsment fejlődése - múlt, jelen és jövő = Development of the Green Supply Chain Management - Past, Present, Future. Vezetéstudomány / Budapest Management Review 50(12): 122-135.

KOZMA, Tímea. 2018. Szereplők, folyamatok, kapcsolatok az ellátási lánc mentén. In: Logisztikai Évkönyv. Budapest: Magyar Logisztikai Egyesület. 23-35.

KOZMA, Tímea-PÓNUSZ, Mónika. 2016. Az ellátásilánc-menedzsment elmélete és gyakorlata - alapok: Alapösszefüggések a hálózati versenyelönyök és értékláncok mentén. Gyöngyös: Károly Róbert Kutató-Oktató Közhasznú Nonprofit Kft. 
LALONDE, J. Bernard-MASTERS, M. James. 1994. Emerging Logistics Strategies: Blueprints for the Next Century. International Journal of Physical Distribution and Logistics Management 24: 35-47.

LAMBERT, M. Douglas-STOCK, R. James-ELLRAM, M. Lisa. 1998. Fundamentals of Logistics Management. Boston: Irwin/McGraw-Hill.

LATAN, Hengky-NOONAN, Richard. 2017. Partial Least Squares Path Modeling: Basic Concepts, Methodological Issues and Applications. Switzerland: Springer.

LOEHLIN, John-BEAUJEAN, Alexander. 2016. Latent Variable Models: An Introduction to Factor, Path, and Structural Equation Analysis. UK: Taylor \& Francis.

LOGÓ, Róbert-PÓNUSZ, Mónika-KOZMA, Tímea. 2016. Hútőipari vállalkozás ellátási láncának értékelése és logisztikai megoldásainak vizsgálata. In: Vágány, Judit-Fenyvesi, Éva (eds), Multidiszciplináris kihívások, sokszínú válaszok, 2. Budapest: BGE KVIK Közgazdasági Intézeti Tanszéki Osztály. 115-137.

MIKE, Gábor. 2002. A logisztika környezetvédelmi kérdései és a reverz logisztika. Occasional Paper No 19.

OLÁH, Judit-NESTLER, Steffen-NOBEL, Thomas-POPP, József. 2018a. Ranking of Dry Ports in Europe - Benchmarking. Periodica Polytechnica Transportation Engineering 46(2): 95-100.

OLÁH, Judit-NESTLER, Steffen-NOBEL, Thomas-HARANGI-RÁKOS, MónikaPOPP, József. 2018b. Development of Dry Ports in Europe. International Journal of Applied Management Science 10(4): 269-289.

OLÁH, Judit-NESTLER, Steffen-NOBEL, Thomas-POPP, József. 2018c. International Characteristics of the Macro-Logistics System of Freight Villages. Periodica Polytechnica Transportation Engineering 46(4): 194-200.

PÓNUSZ, Mónika-HORVÁTH, Annamária. 2014. Zöld logisztikai fejlesztések aspektusai az EU-ban. Conference paper in the context of the Via Futuri 2014 international conference organized at the Faculty of Business and Economics, University of Pécs: Fenntarthatóság - Versenyképesség - Regionális fejlödés, Elméleti kutatások, gyakorlati alkalmazások. 150-157.

PÓNUSZ, Mónika-KOZMA, Tímea. 2017. Zöld ellátási láncok és innovatív megoldások. Logisztikai Trendek és Legjobb Gyakorlatok 3(2): 61-66.

RÉGER, Béla. 2010. A logisztika és az ellátási lánc időszerú kérdései napjainkban. Hadmérnök V(3): 63-68.

SCOR. 2006. SCOR Software Model Framework 2.0. Source: Supply Chain Council, 2006, p. 3. Updated on: 15 March 2013. SCOR Software Model Framework (Supply Chain, Strategic Management).

SZÉKELYI, Mária-BARNA, Ildikó. 2008. Túlélő́készlet az SPSS-hez. Többváltozós elemzési technikákról társadalomkutatók számára. Budapest: Typotex Kiadó. 
TÓTH, Róbert-GYENGE, Balázs. 2018. Az ellátási láncok kialakulása és az ellátási lánc menedzsment értelmezése. In: Duleba, Szabolcs (ed.), Logisztikai Évkönyv. Budapest: Magyar Logisztikai Egyesület. 36-45.

TOUBOULIC, Anne-WALKER, Helen. 2015. Theories in Sustainable Supply Chain Management: A Structured Literature Review. International Journal of Physical Distribution \& Logistics Management 45(1/2): 16-42.

STEVENS, Graham. 1989. Integrating the Supply Chain. International Journal of Physical Distribution and Materials Management 9: 3-8.

VERES, Edit. 2017. Social Behaviour of Companies Executives in Case of SME's in Bihor County. $4^{\text {th }}$ International Multidisciplinary Scientific Conference on Social Sciences \& Arts, SGEM 2017 - Conference Proceedings, Book 1, Modern Science, Volume V, Business and Management. 847-855. DOI: 10.5593/sgemsocial2017/15. WCED. 1987. Our Common Future. https://sustainabledevelopment.un.org/content/ documents/5987our-common-future.pdf. Downloaded on: 16.04.2019. 